Counsellia: Jurnal Bimbingan dan Konseling, 10 (1), $2020 \mid 28-40$

Copyright (02020 Universitas PGRI Madiun

ISSN: 2088-3072 (Print) / 2477-5886 (Online)

Available online at: http://e-journal.unipma.ac.id/index.php/JBK

DOI: 10.25273/counsellia.v10i1.5213

\title{
Solution-Focused Brief Therapy (SFBT) untuk meningkatkan motivasi membaca Murid Disleksia
}

\author{
Fajriani $^{1}$, Yulizar ${ }^{2}$ \\ ${ }^{1}$ Fakultas Keguruan dan Ilmu Pendidikan, Universitas Syiah Kuala, Banda Aceh \\ fajriani@unsyiah.ac.id \\ ${ }^{2}$ SMA Laboratorium Universitas Syiah Kuala, Banda Aceh \\ yulizar.abd@gmail.com
}

\begin{abstract}
Abstrak
Di Indonesia, prevalensi murid disleksia adalah $1 \%$ dari populasi murid sekolah dasar. Artinya, dari 50 juta murid, diperkirakan ada 5 juta murid yang mengalami disleksia. Disleksia adalah masalah kesulitan membaca yang terjadi pada anak-anak dengan penglihatan dan intelektual normal. Karena kesulitannya dalam membaca, murid disleksia cenderung memiliki motivasi membaca yang rendah. Motivasi membaca merupakan sebuah masalah besar yang akan menghambat pencapaian akademik, dan harus segera diselesaikan.. Solution-Focused Brief Therapy bisa menjadi alternatif penyelesaian masalah motivasi membaca yang dialami siswa disleksia sehingga mereka mampu berprestasi secara akademik, sesuai dengan kemampuan intelektual yang dimiliki. Oleh sebab itu, penelitian bertujuan untuk mengetahui seberapa besar efek Solution-Focused Brief Therapy (SFBT) dalam meningkatkan motivasi membaca murid disleksia. Penelitian ini menggunakan desain kuasi eksperimen dengan Non Equivalent Control Group Design yang melibatkan 16 orang murid kelas tinggi pada salah satu sekolah dasar di Aceh Utara, Aceh, Indonesia yang berkemungkinan mengalami masalah disleksia. Untuk menentukan kemungkinan murid mengalami disleksia, digunakan instrumen Senarai Semak Disleksia yang disusun oleh Kementerian Pelajaran Malaysia (KPM) dan Universiti Sains Malaysia (USM). Motivasi membaca ditentukan oleh skor Motivation to Read Profile (MRP). Hasil penelitian menunjukkan bahwa terdapat peningkatan skor motivasi membaca murid yang telah mengikuti intervensi SFBT selama enam sesi, sebesar 106 poin, dengan size effect 1.181 yang berarti bahwa SFBT yang diberikan memberikan efek yang besar dalam meningkatkan motivasi membaca murid disleksia.
\end{abstract}

Keywords : SFBT, Disleksia, Motivasi Membaca.

\begin{abstract}
There are $15 \%$ of elementary school students in the world are dyslexic. Dyslexia is a reading difficulty that occurs in children with normal vision and intellect. Dyslexic students certainly have reading motivation problems. Reading motivation is a big problem that will effect to academic achievement, and must be resolved immediately. Solution-Focused Brief Therapy (SFBT) can be an alternative to increase the reading motivationof dyslexic students, so that they can achieve according to their intellectual abilities. Therefore, this study aims tp find out how much the effect of Solution-Focused Brief Therapy (SFBT) in increasing the reading motivation of dyslexic students. This study uses a quasi-experimental design with Non Equivalent Control Group Design, involving 16 high class students in one of the elementary schools in North Aceh, Aceh,
\end{abstract}


Indonesia who are likely to experience dyslexia problems. To determine the possibility of dyslexia, researchers used the dyslexic checklist instrument compiled by the Malaysian Ministry of Education (KPM) and Universiti Sains Malaysia (USM). The level of reading motivation is determined by the Motivation to Read Profile (MRP) score. The results showed that there was an increase in the reading motivation score of students who had followed SFBT interventions for six sessions, totaling 106 points, with a size effect of 1.181 which meant the given SFBT had a great effect in increasing the reading motivation of dyslexic students.

Keywords : SFBT, Dyslexia, Reading Motivation.

\section{PENDAHULUAN}

Membaca merupakan kemampuan dasar yang harus dikuasai oleh murid dalam pendidikan formalnya. Tanpa kemampuan membaca, maka murid-murid akan mengalami hambatan untuk memperoleh ilmu pengetahuan lainnya. Selain untuk kepentingan pendidikannya, kemampuan membaca juga diperlukan diperlukan agar murid bisa mendapatkan informasi lain dari lingkungan. Untuk mendapatkan kemampuan tersebut, murid-murid melakukan banyak latihan membaca baik itu di sekolah maupun di rumah.

Namun bukan sedikit murid yang mengalami masalah dalam membaca. Sebab, masalah membaca merupakan masalah yang paling sering muncul di kalangan muridmurid sekolah dasar. Masalah membaca bisa terjadi pada murid-murid yang mempunyai kecerdasan normal ataupun di atasnya. Masalah membaca seperti ini disebut dengan masalah pembelajaran spesifik disleksia. Angka kejadian disleksia di berbagai negara cukup bervariasi yaitu di Inggris 5\%, di Amerika 17\%, dan rata-rata di seluruh dunia adalah 15\% (Dewi, 2015).

Diagnostic and Statistical Manual of Mental Disorder (DSM-V-TR) membagikan masalah belajar menjadi tiga kategori yaitu masalah membaca, menulis ekspresif, dan menghitung (American Psychiatric Association, 2015). Murid-murid disleksia mengalami kesukaran untuk mengenali perkataan, memahami bacaan, dan umumnya mengalami kesukaran dalam menulis ejaan. Disleksia ialah ketidakmampuan yang parah dalam membaca, melibatkan kesukaran dalam pemahaman, serta menghubungkan antara bunyibunyi dan huruf-huruf (Texas Education Agency, 2018).

Disamping masalah membaca yang dihadapinya, murid-murid disleksia juga akan mengalami masalah emosional termasuk motivasi membaca. Satu penelitian survei (Polychroni, Koukoura, \& Anagnostou, 2006) bertujuan untuk menelaah motivasi membaca murid-murid disleksia apakah berbeda dengan teman sebaya mereka atau tidak dan hasil penelitian menunjukkan bahwa murid-murid disleksia mempunyai konsep diri yang rendah serta motivasi membaca hanya menunjukkan motif luar saja. Faktor orangtua juga memberikan pengaruh terhadap murid-murid disleksia. Orangtua yang mencari informasi dan menghadiri kelompok dukungan untuk tujuan pendidikan dan penelitian tentang kesukaran pembelajaran yang dialami oleh anak-anak mereka merasa lebih puas dengan pengalaman yang mereka dapatkan dalam kelompok dukungan berbanding dengan orangtua yang menghadiri kelompok dukungan hanya karena saran dari para profesional saja atau untuk tujuan dukungan emosi (Bull, 2003).

Istilah disleksia ini digunakan untuk menggambarkan anak-anak atau orang dewasa yang mempunyai IQ pada tahap normal atau di atasnya namun mempunyai masalah dalam membaca, menulis, mengeja, ataupun menghitung (Armenta, 2010). Bagi sebagian murid disleksia, huruf-huruf dalam suatu kata mempunyai bentuk yang sama dan sukar untuk dibedakan. Sedangkan bagi sebagian yang lain, mereka sukar untuk mengingat perkataan atau mendengar bunyi yang sama pada kata yang berbeda, sehingga membaca 
menjadi hal yang amat sukar dan dibenci. Untuk mengajarkan membaca pada murid disleksia diperlukan metode tertentu seperti metode multisensori.

Murid-murid disleksia cenderung memiliki motivasi yang rendah terhadap membaca karena ketidakmampuannya dalam membaca. Kesukaran dalam membaca menjadikan motivasi membaca murid-murid disleksia menurun. Kondisi seperti ini perlu diselesaikan dengan cepat dan tepat. Salah satu cara yang bisa digunakan untuk membantu murid-murid yang mengalami masalah motivasi membaca ialah dengan memberikan suatu bentuk terapi singkat yang mampu meningkatkan motivasi belajarnya sehingga timbul semangat untuk belajar dan menerima kekurangan dan kelebihan yang dimilikinya.

Pada kenyataannya, banyak model terapi singkat datang dari terapi-terapi utama untuk sekolah. Solution-Focused Brief Therapy (SFBT) memberikan suatu kaedah yang efektif dalam meningkatkan program intervensi membaca. Beberapa penelitian terdahulu telah dilakukan, diantaranya oleh Springer et al (Kim \& Franklin, 2009) yang memberikan SFBT untuk meningkatkan self esteem murid sekolah dasar. Peneliti lain (Saffarpoor, Farahbakhsh, Shafiabadi, \& Pashasharifi, 2011) juga melaksanakan treatment SFBT dalam meningkatkan penyesuaian sosial, dan terbukti efektif.

Berdasarkan hasil penelitian, murid-murid disleksia mempunyai kemampuan literasi yang rendah, motivasi yang rendah, cenderung menghindari tugas dan pada akhirnya akan mengakibatkan trauma secara emosional (Altamimi, 2016). Solution Focused Brief Therapy (SFBT) membantu murid-murid disleksia agar dapat memahami diri sendiri terhadap kekurangan dan kelebihan yang mereka miliki. Tujuannya ialah agar murid-murid disleksia dapat melihat secara objektif dan tidak hanya berfokus pada kekurangannya sebagai murid-murid dengan gangguan disleksia. Oleh karena itu, peneliti ingin menyelidiki lebih lanjut tentang efek SFBT dalam meningkatkan motivasi membaca murid. Murid yang dimaksud adalah murid sekolah dasar yang mempunyai kemungkinan mengalami disleksia.

Secara lebih rinci, penelitian ini dijalankan untuk: pertama, mengukur efektivitas SFBT terhadap motivasi membaca murid disleksia berdasarkan perbedaan : a. Skor pre dan pos tes motivasi membaca pada setiap s ubjek dalam kelompok intervensi, b. Skor pre dan pos tes motivasi membaca pada setiap subjek dalam kelompok control, c. Nilai rata-rata pre dan pos tes motivasi membaca pada kelompok intervensi, dan d. Nilai ratarata pre dan pos tes motivasi membaca pada kelompok kontrol. Dan tujuan kedua untuk mengukur effect size intervensi SFBT terhadap motivasi membaca bagi murid-murid disleksia.

Penelitian ini menggunakan format dan struktur sesi yang dikemukakan oleh de Shazer, et al (Trepper \& Mccollum, 2010) yaitu dengan pre session change, goal, miracle question, scaling question, constructing soluiton \& exception, coping question, and experiment \& homework assignment. Kerangka konseptual penelitian ini dapat digambarkan sebagai berikut :

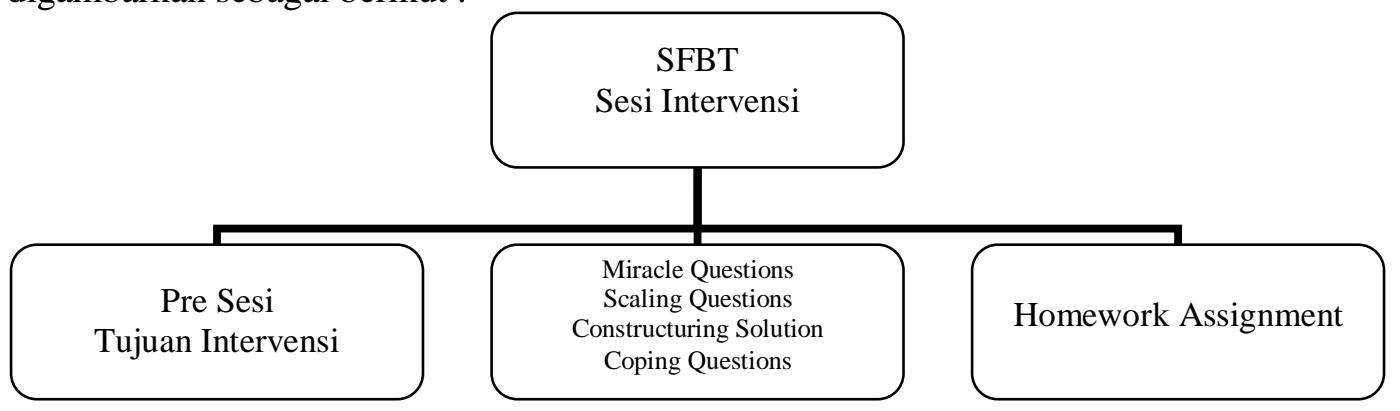

Gambar 1. Kerangka Konseptual Penelitian 


\section{METODE PENELITIAN}

\section{Rancangan Penelitian}

Penelitian menggunakan desain penelitian kuasi eksperimental dengan Non Equivalent Control Group Design. Subjek penelitian adalah murid di Sekolah Dasar Negeri 12 Samudera, Aceh Utara kelas IV, V dan VI. Murid ini diperkirakan mengalami disleksia, dan telah disaring menggunakan ujian saringan (Screening Test) yang bernama Senarai Semak Disleksia (Kementerian Pelajaran Malaysia, 2011) dan Universiti Sains Malaysia.

\section{Sumber Data}

Sampel penelitian adalah 30 orang murid-murid Sekolah Dasar Negeri 12 Samudera, Kabupaten Aceh Utara yang berkemungkinan mengalami disleksia. Metode pemilihan sampel adalah dengan pensampelan acak berpasangan (The Matched Pairs Design).

\section{Teknik Pengumpulan Data}

Untuk mengukur motivasi membaca digunakan instrumen Motivation to Read Profile (MRP)-Revised (Malloy, Marinak, Gambrell, \& Mazzoni, 2013). Item ganjil dalam instrumen ini mewakili Self Concepft of Reader dan item genal mewakili Value of Reading. Instrumen ini diberikan secara individual. Nilai setiap sampel dicatat dan dijadikan data awal untuk menjalankan intervensi SFBT. Setelah pemberian intervensi, sampel akan diuji kembali dengan menggunakan instrumen yang sama untuk mengetahui apakah intervensi yang diberikan efektif atau tidak dalam meningkatkan kemampuan membaca murid-murid disleksia. Dalam penelitian ini, MRP diadministrasikan secara berkelompok. Peneliti membaca dengan keras setiap item pertanyaan untuk menghindari kesalahan yang disebabkan murid tidak bisa membaca pertanyaan tersebut, seperti yang pernah dilakukan oleh peneliti sebelumnya (D. M. Smith, 2011).

\section{Teknik Analisis Data}

Analisis deskriptif, peneliti akan melihat perbandingan skor setiap subjek dalam kelompok diantara pre dan pos tes. Sedangkan untuk berkelompok, peneliti akan membandingkan nilai rata-rata yang diperoleh diantara pre dan pos tes pada setiap kelompok. Perbedaan ini akan digambarkan dalam grafik. Analisis deskriptif dilakukan karena sampel penelitian berjumlah sedikit dan tidak memungkinkan untuk dilakukan analisis secara statistik. Adapun untuk menentukan efek suatu intervensi yang diberikan, Campbell \& Stanley (Cohen, Manion, \& Morrison, 2012) mengemukakan langkahlangkah dalam perhitungan efek sebab-akibat intervensi yang diberikan yaitu sebagai berikut:

$$
\left(O_{2}-R O_{1}\right)-\left(O_{4}-R O_{3}\right)
$$

Gambar 1. Formula untuk Menentukan Efek Intervensi

Keterangan :

O2 : Pos tes kelompok intervensi

RO1 : Pre tes kelompok intervensi

O4 : Pos tes kelompok kontrol

RO3 : Pre tes kelompok kontrol

Jika hasil bernilai negatif, maka efek sebab-akibat juga bernilai negatif. Artinya, jika variabel bebas menurun, maka akan mengakibatkan variabel terikat mengalami peningkatan. Jika hasil bernilai positif, maka sebaliknya yakni variabel bebas dan terikat 
akan sama-sama meningkat atau menurun. Intervensi yang diberikan kepada kelompok intervensi menggunakan format kelompok dengan anggota 8-10 orang. Desain intervensi SFBT dijelaskan dalam tabel 1. Perhitungan effect size mempertimbangkan ukuran perbedaan skor nilai rata-rata yang diperoleh, tanpa mempertimbangkan apakah hasil penelitian signifikan atau tidak (Fraenkel \& Wallen, 2003). Untuk kebanyakan peneliti, effect size yang diperoleh $>0.5$ ke atas maka hasil penelitian itu sudah dianggap sebagai hasil penting (Fraenkel \& Wallen, 2003).

Tabel 1. Rencana Intervensi

\begin{tabular}{|c|c|}
\hline $\begin{array}{c}\text { TAHAP } \\
\text { (100 Menit) }\end{array}$ & KEGIATAN \\
\hline $\begin{array}{l}\text { SESI TRANSISI } \\
\text { Membina Hubungan }\end{array}$ & $\begin{array}{l}\text { 1. Siapa Saya? } \\
\text { 2. Menggambarkan Dunia } \\
\text { 3. Tiga Hal yang Dipelajari Hari Ini } \\
\text { 4. Tugas Rumah }\end{array}$ \\
\hline $\begin{array}{l}\text { TAHAP } 1 \\
\text { Top } 10 \text { Exercise }\end{array}$ & $\begin{array}{l}\text { 1. } 10 \text { Hal Terbaik yang Berlaku Pada Minggu Lalu } \\
\text { 2. Diskusi Tugas Rumah } \\
\text { 3. Strategi Membaca yang Menyenangkan } \\
\text { 4. Pertanyaan Skala } \\
\text { 5. Tugas Rumah (Praktik) } \\
\end{array}$ \\
\hline $\begin{array}{l}\text { TAHAP } 2 \\
\text { Miracle Questions }\end{array}$ & $\begin{array}{l}\text { 1. Diskusi keberhasilan membaca } \\
\text { 2. Pertanyaan skala } \\
\text { 3. Apa yang berbeda? } \\
\text { 4. Pertanyaan ajaib }\end{array}$ \\
\hline $\begin{array}{l}\text { TAHAP } 3 \\
\text { Reading Game }\end{array}$ & $\begin{array}{l}\text { 1. Membaca satu paragraf bacaan } \\
\text { 2. Mendapatkan hadiah } \\
\text { 3. Strategi membaca } \\
\text { 4. Tugas Rumah }\end{array}$ \\
\hline $\begin{array}{l}\text { TAHAP } 4 \\
\text { Helping Hand }\end{array}$ & $\begin{array}{l}\text { 1. Mengkaji tugas rumah } \\
\text { 2. Strategi membaca khusus } \\
\text { 3. Siapa yang bisa membantumu membaca? } \\
\text { 4. Helping Hand Exercise }\end{array}$ \\
\hline $\begin{array}{l}\text { TAHAP } 5 \\
\text { Creative Exercise }\end{array}$ & $\begin{array}{l}\text { 1. Mengkaji kembali strategi membaca yang dipilih } \\
\text { 2. Menggambarkan strategi membaca yang dipilih } \\
\text { 3. Penutup }\end{array}$ \\
\hline KELOMPOK KONTROL & Tidak mendapatkan terapi \\
\hline
\end{tabular}

\section{HASIL DAN PEMBAHASAN}

\section{Hasil Penelitian}

Berdasarkan saran yang diberikan oleh guru kelas, sebanyak 30 orang murid kelas IV, V dan VI yang mempunyai masalah dalam membaca dipilih menjadi calon subjek penelitian. Guru kelas kelas IV, V, dan VI memberikan informasi tentang diri murid yang disarankan dengan mengisi instrumen saringan disleksia Kementerian Pelajaran Malaysia dan didapatlah 16 orang murid yang berkemungkinan mengalami disleksia. Jumlah subjek penelitian dipaparkan dalam Tabel 2 .

Tabel 2. Jumlah Pembagian Subjek Penelitian

\begin{tabular}{lccc}
\hline \multirow{2}{*}{ Kategori } & \multicolumn{2}{c}{ Jenis Kelamin } & \multirow{2}{*}{ Jumlah } \\
\cline { 2 - 3 } & Lk & Pr & \\
\hline Berkemungkinan Disleksia & 7 & 9 & 16 \\
\hline Tidak Berkemungkinan Disleksia & 13 & 1 & 14 \\
\hline Jumlah & 20 & 10 & 30 \\
\hline
\end{tabular}


Sebanyak 16 orang murid (tabel 3) yang berkemungkinan mengalami masalah pembelajaran spesifik disleksia telah dipilih untuk menjadi subjek penelitian. Oleh karena murid-murid yang menjadi subjek penelitian menghadapi masalah dalam membaca, maka peneliti membantu murid untuk menjawab instrumen MRP dengan membacakan setiap item pada instrumen. Intervensi SFBT diberikan selama enam hari berturut-turut. Dalam pemberian intervensi, murid-murid dikumpulkan di dalam satu ruang kelas sehingga tidak mengganggu kegiatan pembelajaran murid lainnya yang tidak termasuk dalam subjek penelitian.

Tabel 3. Sebaran Subjek Berdasarkan Jenis Kelamin

\begin{tabular}{|c|c|c|c|}
\hline \multirow{2}{*}{ Kelompok } & \multicolumn{2}{|c|}{ Jenis Kelamin } & \multirow{2}{*}{ Jumlah } \\
\hline & Lk & Pr & \\
\hline Intervensi & 3 & 5 & 8 \\
\hline Kontrol & 4 & 4 & 8 \\
\hline
\end{tabular}

\section{Skor Secara Individu Subjek Kelompok Intervensi dan Kelompok Kontrol}

\section{Kelompok Intervensi}

Hasil penelitian secara individu untuk kelompok Intervensi dipisahkan menjadi dua bagian mengikut instrumen penelitian yang diberikan. Tabel 4 menunjukkan bahwa Intervensi SFBT yang diberikan kepada subjek penelitian adalah efektif dalam meningkatkan motivasi membaca. Ini dibuktikan dengan skor yang diperolehi oleh subjek memperlihatkan peningkatan skor motivasi dalam ujian pos berbanding skor ujian pra. Peningkatan skor motivasi membaca berada diantara 15-21 poin.

Tabel 4. Hasil Analisis Deskriptif Perbedaan Skor MRP Pre dan Pos Tes Subjek Kelompok Intervensi

\begin{tabular}{cccc}
\hline Subjek & Skor Pre Tes & Skor Pos Tes & Peningkatan Skor \\
\hline 1 & 45 & 60 & 15 \\
\hline 2 & 39 & 57 & 18 \\
\hline 3 & 40 & 61 & 21 \\
\hline 4 & 42 & 60 & 18 \\
\hline 5 & 42 & 60 & 18 \\
\hline 6 & 49 & 65 & 16 \\
\hline 7 & 40 & 57 & 17 \\
\hline 8 & 51 & 68 & 17 \\
\hline
\end{tabular}

\section{Kelompok Kontrol}

Hasil penelitian untuk kelompok kontrol mengikut perolehan skor individu menurut instrumen MRP ditunjukkan dalam tabel 5.

Tabel 5. Hasil Analisis Deskriptif Perbedaan Skor MRP Pre dan Pos Tes Subjek Kelompok Kontrol

\begin{tabular}{cccc}
\hline Subjek & Skor Pre tes & Skor Pos Tes & Peningkatan Skor \\
\hline 1 & 64 & 70 & 6 \\
\hline 2 & 50 & 54 & 4 \\
\hline 3 & 41 & 45 & 4 \\
\hline 4 & 44 & 48 & 4 \\
\hline 5 & 48 & 53 & 5 \\
\hline
\end{tabular}




\begin{tabular}{cccc}
\hline Subjek & Skor Pre tes & Skor Pos Tes & Peningkatan Skor \\
\hline 6 & 36 & 39 & 3 \\
\hline 7 & 40 & 43 & 3 \\
\hline 8 & 40 & 45 & 5 \\
\hline
\end{tabular}

Dari Tabel 5, dapat disimpulkan bahwa ada sedikit peningkatan skor motivasi membaca (3-6 poin). Peningkatan ini boleh disebabkan oleh motivasi yang diberikan oleh guru dalam aktiviti pengajaran dan pembelajarannya. Ini dibuktikan dengan skor yang diperolehi oleh semua subjek memperlihatkan peningkatan skor motivasi dalam ujian pos berbanding skor ujian pra.

\section{Nilai rata-rata Keseluruhan Skor Instrumen Penelitian}

Nilai rata-rata instrumen penelitian Motivation to Read Profile (MRP) dapat dilihat dalam tabel 6. Tabel 6 menunjukkan bahwa kelompok Intervensi mengalami peningkatan nilai rata-rata pre tes dan pos tes $(p r e=43.5$, pos $=61.0$ ), sedangkan kelompok kontrol juga menunjukkan peningkatan nilai rata-rata pada pre tes dan pos tes (pre $=45.4$, pos= 49.6). Namun begitu, peningkatan nilai rata-rata motivasi kelompok kontrol hanya sedikit yaitu 4.2 poin, jika dibandingkan dengan peningkatan nilai rata-rata motivasi kelompok intervensi, yaitu 17.5 poin.

Tabel 6. Hasil Analisis Deskriptif Perbedaan Nilai rata-rata Motivasi Membaca (MRP) Pre dan pos tes pada Kelompok Intervensi dan Kontrol

\begin{tabular}{lcc}
\hline Kelompok & Nilai rata-rata Pre Tes & Nilai rata-rata Pos Tes \\
\hline Intervensi & 43.5 & 61.0 \\
\hline Kontrol & 45.4 & 49.6
\end{tabular}

Gamabaran perolehan nilai rata-rata Pre dan pos tes bagi kedua kelompok disajikan pada gambar 2 .

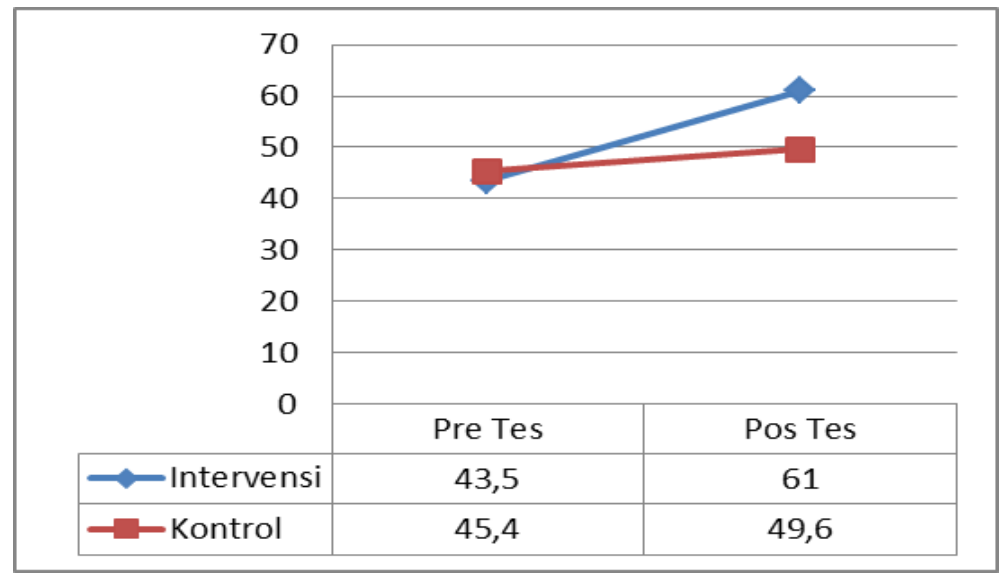

Gambar 2. Perbandingan Nilai rata-rata Keseluruhan Motivasi Membaca Kelompok Intervensi dan Kontrol

\section{Efek Sebab Akibat Intervensi}

Menggunakan istilah Campbell dan Stanley (Cohen et al., 2012), efek sebab akibat dari Intervensi SFBT yang diberikan pada kelompok Intervensi dan kontrol dalam meningkatkan motivasi membaca murid adalah bernilai positif yaitu sebesar 106 poin yaitu seperti dalam tabel 7 . 
Tabel 7. Perhitungan Efek Sebab Akibat Intervensi SFBT pada Motivasi Membaca pada Kelompok Intervensi dan Kontrol

\begin{tabular}{ccccc}
\hline \multirow{2}{*}{ Subjek } & \multicolumn{2}{c}{ Kelompok Intervensi } & \multicolumn{2}{c}{ Kelompok Kontrol } \\
\cline { 2 - 5 } & Pos Tes $\left(\mathrm{O}_{2}\right)$ & Pre Tes $\left(\mathrm{RO}_{1}\right)$ & Pos Tes $\left(\mathrm{O}_{4}\right)$ & Pre Tes $\left(\mathrm{RO}_{3}\right)$ \\
\hline 1 & 60 & 45 & 70 & 64 \\
\hline 2 & 57 & 39 & 54 & 50 \\
\hline 3 & 61 & 40 & 45 & 41 \\
\hline 4 & 60 & 42 & 48 & 44 \\
\hline 5 & 60 & 42 & 53 & 48 \\
\hline 6 & 65 & 49 & 39 & 36 \\
\hline 7 & 57 & 40 & 43 & 40 \\
\hline 8 & 68 & 51 & 45 & 40 \\
\hline Jumlah & 488 & 348 & 397 & 363 \\
\hline \multicolumn{6}{c}{ Efek Sebab $\left.\mathrm{Akibat}_{2}-\mathrm{RO}_{1}\right)$} & 140 & $\left(\mathrm{O}_{4}-\mathrm{RO}_{3}\right)$ & 34 \\
\hline
\end{tabular}

\section{Effect Size}

Effect size dari penelitian yang dijalankan dihitung mengikut instrumen penelitian yang dijalankan pada kedua kelompok subjek. Untuk mengetahui effect size Intervensi perlu dihitung dengan menggunakan formula seperti yang telah disebutkan dalam box 1 . Effect size Intervensi SFBT bagi motivasi membaca bernilai lebih dari 0.5, maka Intervensi SFBT yang dijalankan terhadap subjek penelitian dalam kelompok Intervensi ialah efektif dalam meningkatkan motivasi membaca murid yang berkemungkinan mengalami disleksia. Adapun hasil perhitungan effect size Intervensi SFBT terhadap motivasi membaca murid ditunjukkan dalam tabel 8 .

Tabel 8. Hasil Perhitungan Effect Size Intervensi SFBT untuk Motivasi Membaca Murid Menggunakan Instrumen MRP

\begin{tabular}{cc}
\hline \multicolumn{1}{c}{ Hasil Perhitungan } & MRP \\
\hline Nilai rata-rata Kelompok Intervensi & 61 \\
\hline Nilai rata-rata Kelompok Kontrol & 49.63 \\
\hline Standar Deviasi Kelompok Kontrol & 9.62 \\
\hline Effect Size & 1.181 \\
\hline
\end{tabular}

\section{Pembahasan}

Hasil penelitian ini menyimpulkan bahwa SFBT efektif dan dapat dijadikan sebagai salah satu intervensi alternatif untuk meningkatkan motivasi membaca murid disleksia. Dalam SFBT, masalah-masalah kompleks yang dialami individu diselesaikan dengan membantu murid menentukan langkah-langkah kecil dalam arahan yang positif (Daki, 2008). Hal ini sesuai dengan langkah-langkah intervensi yang dilakukan dalam penelitian ini untuk meningkatkan motivasi belajar murid disleksia. Dimana pada tahap intervensi pertama, murid diminta untuk merumuskan strategi belajar yang paling menyenangkan menurutnya, dilanjutkan dengan permainan membaca, dan merumuskan strategi membaca yang lebih spesifik sehingga motivasi membaca murid disleksia meningkat. 
Penelitian sebelumnya yang juga membuktikan bahwa SFBT bisa meningkatkan motivasi membaca, self-esteem, dan sikap siswa terhadap sekolah pada 14 orang subjek penelitian (Daki \& Savage, 2010). Dalam penelitian tersebut, peneliti menggunakan SFBT untuk meningkatkan motivasi akademik pada 14 siswa yang mengalami kesulitan membaca. Pada kelompok intervensi, diberikan lima sesi SFBT selama 40 menit pada masing-masing sesi. Sedangkan untuk kelompok kontrol diberikan dukungan akademik untuk pekerjaan rumahnya. Berbeda dengan penelitian sebelumnya, penelitian ini memberikan intervensi SFBT selama 60 menit dalam lima sesi, sedangkan untuk kelompok kontrol tidak diberikan intervensi apapun.

Penelitian yang sama juga dilakukan oleh peneliti lain yakni penggunaan SFBT untuk meningkatkan self esteem pada siswa dan mahasiswa. Pada siswa, peneliti menggunakan Konseling islami dengan SFBT pada 4 orang subjek dengan 4 sesi terapi dan hasilnya adalah SFBT dalam konteks konseling islami terbukti dapat meningkatkan self esteem siswa yang rendah (78.50) mejadi tinggi (123.50) pada skala self esteem Copersmith (Kaharja \& Latipah, 2016). Sedangkan pada mahasiswa, SFBT diberikan pada mahasiswa yang merasa tidak puas dengan dirinya, memandang berbagai kejadian dalam hidupnya sebagai hal yang negatif, dan merasa tidak mampu membantu dirinya sendiri. Hasil penelitian pada mahasiswa ini menunjukkan bahwa SFBT mempunyai efek pada perubahan terapeutik untuk peningkatan harga diri (self esteem) mahasiswa (Rusandi \& Rachman, 2014).

Penelitian lain juga menyatakan bahwa SFBT memberikan efek yang positif terhadap motivasi. Penelitian (Mckergow \& Korman, 2009) mendapatkan hasil bahwa intervensi SFBT bisa mengubah beberapa variabel seperti kepercayaan, kepribadian, sikap, motivasi, nilai, pemikiran, emosi, jiwa, peta mental, kelemahan dan kekuatan pada diri subjek. Dalam penelitian tersebut, peneliti mengkaji lebih banyak aspek yang dapat ditingkatkan dengan intervensi SFBT yang diberikan, sampai kepada mengevaluasi kelebihan dan kekurangan yang dimiliki oleh klien yang diberikan intervensi.

Bukan hanya untuk motivasi membaca, intervensi SFBT bahkan dapat meningkatkan kemampuan membaca anak-anak. Seperti disebukan dalam penelitian eksperimental (Woods, Bond, Humphrey, Symes, \& Green, 2011) yang memberikan intervensi SFBT pada anak-anak dan hasilnya adalah SFBT dapat meningkatkan kemampuan membaca mereka. Untuk beberapa variabel lain, SFBT juga memberikan efek yang positif. Penggunaan SFBT mampu meningkatkan rasa optimis, resiliensi klien, dan kontrol diri (Roeden, Maaskant, \& Curfs, 2014). Demikian pula halnya dengan penelitian (Bozeman, 2000) yang mendapati bahwa effect size penggunaan SFBT bagi meningkatkan skor skala harapan secara signifikan adalah sebesar 1.09. Dengan demikian dapat disimpulkan bahwa Intervensi SFBT yang diberikan efektif dalam meningkatkan rasa optimis, motivasi, sikap, empati, dan harapan.

Beberapa literatur menunjukkan bahwa SFBT dapat digunakan pada berbagai subjek penelitian, bukan hanya pada subjek yang mengalami disleksia, namun subjek dengan gangguan intelektual ringan (Mild Intellectual Disabilities/MID) pun mendapatkan efek yang positif setelah diberikan intervensi SFBT (Roeden et al., 2014). Training SFBT juga pernah diberikan secara intensif selama 6 bulan kepada perawat di sekolah kesehatan di Inggris dan hasilnya adalah hubungan interpersonal antara perawat dengan pasien berubah menjadi lebih baik, perawat menjadi lebih percaya diri dalam menjalankan tugas profesionalnya, dan lebih antusias dalam bekerja (S. Smith, 2010).

Dalam sesi konseling, pemberian intervensi SFBT telah dilakukan oleh beberapa peneliti baik dalam setting konseling individual maupun konseling kelompok. Pada sesi konseling individual, penggunaan SFBT/SFBC dapat meningkatkan konsep diri akademik siswa (Nugroho, Puspita, \& Mulawarman, 2018). Pada sesi konseling kelompok, 
intervensi SFBC yang diberikan kepada siswa Sekolah menengah di Jawa Timur memberikan efek positif, dimana perilaku agresi siswa yang tinggi, dapat diturunkan setelah melalui 4 sesi SFBC (Fitriyah, 2018). Masih dalam sesi konseling kelompok, SFBC diberikan pada sekelompok mahasiswa akhir untuk meningkatkan planned happenstance skill, dan SFBC memberikan efek positif dan signifikan (Rusandi, Sugiharto, \& Sunawan, 2019).

Bukan hanya dalam setting sekolah, SFBC juga digunakan dalam setting konseling keluarga. Beberapa penelitian terdahulu telah menunjukkan efektivitas SFBC dalam penyelesaian konflik keluarga. Diantaranya, SFBC digunakan dalam sesi konseling keluarga untuk meningkatkan kemandirian anggota keluarga dalam mencari solusi terhadap masalah-masalah keluarga yang timbul (Sumarwiyah, Zamroni, \& Hidayati, 2015). Selain itu, SFBT juga digunakan sebagai treatment dalam hubungan antara pasangan suami istri, SFBC memungkinkan pasangan untuk mengatasi konflik, membangun harapan dan mencari solusi terhadap masalah dalam keluarga (Latif \& Musfirah, 2019).

Beberapa hasil penelitian yang dipaparkan di atas mendukung hasil penelitian ini, dimana SFBT yang diberikan kepada subjek penelitian bukan hanya meningkatkan motivasi, namun juga dapat meningkatkan beberapa variabel yang lain. Demikian pula halnya dengan perhitungan effect size dari intervensi SFBT. Hasil penelitian ini memberikan beberapa implikasi terhadap bidang keilmuan bimbingan dan konseling, pendidikan luar biasa, implikasi terhadap praktik pendidikan di sekolah, implikasi kepada orangtua, dan implikasi kepada murid disleksia itu sendiri.

Implikasi terhadap keilmuan bimbingan dan konseling yaitu Guru Bimbingan Konseling juga bisa memberikan intervensi SFBT kepada siswa-siswa di sekolah untuk membantu mengatasi masalah psikologis yang mereka alami. Guru BK juga bisa menghasilkan berbagai modul baru untuk diaplikasikan dalam sesi Intervensi SFBT dengan permasalahan yang dihadapi oleh siswa di sekolah. Dengan mempelajari prinsipprinsip dalam SFBT, guru Bimbingan Konseling dapat membantu murid secara individual untuk mengatasi berbagai masalah psikologis yang dialaminya. Teknik SFBT akan mengontrol keberhasilan akademik murid-murid dan membantu mereka mencapai tujuan utama dalam pendidikannya.

Intervensi SFBT yang diberikan dapat membantu pihak sekolah untuk mengidentifikasi dan menyelesaikan masalah-masalah yang dihadapi oleh siswa terutama yang berkaitan dengan akademik. Hasil Intervensi SFBT yang dijalankan mampu memberikan keyakinan kepada guru mata pelajaran, guru kelas, atau guru bimbingan konseling dalam mempraktikkan SFBT untuk membantu lebih banyak murid yang menghadapi masalah psikologis yang hampir sama dengan subjek penelitian ini.

Selain itu, SFBT menawarkan kesempatan besar untuk mendukung guru dalam proses pembelajaran di kelas.dengan mempelajari prinsip-prinsip SFBT, guru bisa membuat alat/bahan bantu mengajar yang lebih menarik dan efektif untuk membantu siswa secara individual dan dalam mengelola kelas. Teknik SFBT akan mengontrol keberhasilan akademik siswa dan membantu mereka mencapai tujuan utama. Flexibility SFBT memungkinkan guru mengintegrasikan strategi lain seperti kegiatan berasaskan seni, project berkelompok, dan permainan membaca (Daki, 2008).

Bukan hanya di sekolah, kehidupan keluarga juga memberikan peran penting untuk kesuksesan murid-murid yang berkemungkinan mengalami masalah pembelajaran spesifik disleksia. Orangtua dapat menjalankan beberapa kegiatan dalam Intervensi SFBT bersama anak sehingga tidak hanya upaya dari guru di sekolah saja, namun orangtua pun turut memberikan sumbangan yang berarti dalam meningkatkan motivasi membaca murid 
disleksia. Orangtua dapat mempelajari teknik SFBT untuk menyediakan lingkungan rumah yang dapat membantu anaknya yang mengalami masalah membaca.

Braten, Lie, Andreassen \& Olausen (Daki \& Savage, 2010) menyatakan bahwa pengalaman membaca di rumah seperti ketersediaan buku, berbagi buku bacaan, dan sikap orangtua terhadap membaca akan memberikan pengaruh yang kuat bagi praktik membaca, keterlibatan anak dan prestasinya. Penelitian ini diharapkan dapat membantu orangtua yang mempunyai anak disleksia sehingga bisa meningkatkan motivasi membacanya.

Adapun implikasi penelitian ini terhadap siswa disleksia sendiri adalah SFBT bisa melengkapi program pendidikan yang telah diikuti oleh siswa. Melalui SFBT, siswa yang telah mendapatkan program pendidikan khusus bisa mengembangkan strategi membaca yang lebih efektif untuk membantu meningkatkan penguasaan kemampuan membaca. Secara keseluruhannya, intervensi SFBT membantu siswa untuk mengembangkan kemampuan membaca yang paling utama dan menciptakan kepercayaan diri yang lebih besar (Daki, 2008).

Penelitian ini dilaksanakan dalam waktu yang singkat, oleh sebab itu peneliti tidak dapat memberikan follow up terhadap efek intervensi SFBT pada motivasi membaca subjek penelitian setelah intervensi selesai dilakukan. Pertanyaan yang mungkin muncul adalah sejauh mana dan selama apa efek intervensi SFBT mampu bertahan dalam diri subjek penelitian. Untuk memastikan ketahanan efek SFBT ini, maka diperlukan evaluasi secara berkala. Subjek penelitian perlu diuji dan diukur kembali motivasi membacanya selama jangka waktu tertentu, baik dua bulan sekali atau empat bulan sekali setelah selesai pemberian intervensi. Melalui pengujian susulan ini, reliabilitas intervensi SFBT dapat terjamin.

Hal terakhir yang menjadi bahan pertimbangan bagi peneliti selanjutnya adalah penelitian ini dilakukan di sekolah yang berada di kota kecamatan. Hampir keseluruhan orangtua siswa di sekolah ini mempunyai taraf pendidikan dan ekonomi menengah ke bawah. Maka disarankan untuk penelitian selanjutnya dapat dialihkan pada subjek penelitian di perkotaan untuk melihat efek SFBT. Sebagai tambahan, jumlah sampel penelitian dapat diperbanyak sehingga hasil penelitian dapat dianalisis lebih mendalam menggunakan statistik sehingga hasilnya dapat digeneralisasikan kepada populasi yang lebih luas.

\section{SIMPULAN}

Hasil penelitian menunjukkan bahwa terdapat perbedaan skor kelompok intervensi dan kelompok kontrol, baik secara individual maupun secara rata-rata. Hasil perhitungan effect size menunjukkan bahwa intervensi SFBT yang diberikan kepada siswa yang berkemungkinan disleksia dapat dikatakan efektif dalam meningkatkan motivasi membaca murid disleksia.

\section{UCAPAN TERIMAKASIH}

Penelitian ini tidak terlepas dari bantuan pihak-pihak terkait yang telah memberikan kerjasama yang sangat baik. Terimakasih kepada kepala sekolah dan seluruh Guru di SD Negeri 12 Samudera, Aceh Utara, Provinsi Aceh. Terimakasih kepada murid-murid yang telah berpartisipasi aktif dalam proses penelitian dari awal hingga penelitian ini selesai.

\section{DAFTAR PUSTAKA}

Altamimi, R. (2016). Understanding Dyslexia (University of Exeter). Retrieved from https://pdfs.semanticscholar.org/ff4f/2cd4c8ae965f765bba576f556897c156b00b. pdf 
American Psychiatric Association. (2015). Supplement To Diagnostic and Statistical Manual of Mental Disorders. In Diagnostic and Statistical Manual of Mental Disorders (5th ed.).

Armenta, J. M. (2010). Dyslexia, dysgraphia, and dyscalculia (pp. 1-2). pp. 1-2. Armenta Learning Academy.

Bozeman, B. (2000). The efficacy of solution-focused therapy techniques on perception of hope in clients with depressive symptoms. In Unpublished Doctoral Dissertation. New Orleans. IA.

Bull, L. (2003). The Use of Support Groups by Parents of Children with Dyslexia. Early Child Development and Care, 173(2-3), 341-347. https://doi.org/10.1080/0300443031000071923

Cohen, L., Manion, L., \& Morrison, K. (2012). Research methods in education. In Professional Development in Education (Sixth, Vol. 38). https://doi.org/10.1080/19415257.2011.643130

Daki, J. (2008). Solution Focused Brief Therapy: Addressing Academic, Motivational, Social and Emotional Difficulties of Older Children with Reading Deficits. McGill University, Montreal.

Daki, J., \& Savage, R. S. (2010). Solution-Focused Brief Therapy : Impacts on Academic and Emotional Difficulties. The Journal of Educational Research, 103, 309-326. https://doi.org/10.1080/00220670903383127

Dewi, K. (2015). Disleksia. Prosiding Seminar Nasional PGSD UPY, 7-13. Retrieved from http://repository.upy.ac.id/407/1/artikel kristiantini.pdf

Fitriyah, F. K. (2018). Reducing Aggressive Behavior Using Solution-Focused Brief Counseling (Sfbc). JBKI (Jurnal Bimbingan Konseling Indonesia), 2(2), 34-39.

Fraenkel, J. R., \& Wallen, N. E. (2003). How to Design and Evaluate Research in Education (5th ed.). New York: McGraw-Hill.

Kaharja, \& Latipah, E. (2016). Pengaruh Konseling Islami Solution Focused Brief Therapy terhadap Self-Esteem Siswa MTsN Bantul Kota Tahun 2015/2016. Jurnal Pendidikan Agama Islam, 13(1), 99-116.

Kementerian Pelajaran Malaysia. (2011). Instrumen Senarai Semak Disleksia (ISD) (2nd ed.). Malaysia: Kementerian Pelajaran Malaysia.

Kim, J. S., \& Franklin, C. (2009). Solution-focused brief therapy in schools: A review of the outcome literature. Children and Youth Services Review, 31(4), 464-470. https://doi.org/10.1016/j.childyouth.2008.10.002

Latif, S., \& Musfirah, M. (2019). Model Hipotetik: Pendekatan Solution-Focused Brief Counseling (SFBC) dalam Keluarga. Indonesian Journal of Educational Counseling, 3(1), 11-20. https://doi.org/10.30653/001.201931.81

Malloy, J. A., Marinak, B. A., Gambrell, L. B., \& Mazzoni, S. A. (2013). Assessing motivation to read: The motivation to read profile-revised. Reading Teacher, 67(4), 273-282. https://doi.org/10.1002/trtr.1215

Mckergow, M., \& Korman, H. (2009). Inbetween-Neither Inside Nor Outside: The Radical Simplicity of Solution-Focused Brief Therapy. Journal of Systematic Therapies, 28(2), 34-49.

Nugroho, A. H., Puspita, D. A., \& Mulawarman. (2018). Penerapan Solution-Focused Brief Counseling (SFBC) untuk Meningkatkan Konsep Diri Akademik Siswa. Bikotetik (Bimbingan Dan Konseling: Teori Dan Praktik), 2(1), 73-114. https://doi.org/10.26740/bikotetik.v2n1.p93-99

Polychroni, F., Koukoura, K., \& Anagnostou, I. (2006). Academic self-concept, reading attitudes and approaches to learning of children with dyslexia: do they differ from 
their peers? European Journal of Special Needs Education, 21(4), 415-430. https://doi.org/10.1080/08856250600956311

Roeden, J. M., Maaskant, M. A., \& Curfs, L. M. G. (2014). Processes and effects of solution-focused brief therapy in people with intellectual disabilities: A controlled study. Journal of Intellectual Disability Research, 58(4), 307-320. https://doi.org/10.1111/jir.12038

Rusandi, M. A., \& Rachman, A. (2014). Keefektifan Solution Focused Group Counseling untuk meningkatkan Planned Happenstance Skills dan Career Decision Self Efficacy Mahasiswa BK FKIP Universitas Lambung Mangkurat Banjarmasin. Al 'Ulum, 62(4), 22-28.

Rusandi, M. A., Sugiharto, D. Y. P., \& Sunawan, S. (2019). Effectiveness of solutionfocused group counseling to improve planned happenstance skills of student. Jurnal Konseling Dan Pendidikan, 7(1), 30. https://doi.org/10.29210/127600

Saffarpoor, S., Farahbakhsh, K., Shafiabadi, A., \& Pashasharifi, H. (2011). The Effectiveness of Solution-Focused Brief Therapy on Increasing Social Adjustment of Female Students Residing in Tehran University Dormitories. International Journal of Psychology and Counselling, 3(2), 24-28. Retrieved from http://academicjournals.org/IJPC/PDF/Pdf2011/Feb/Saffarpoor et al.pdf

Smith, D. M. (2011). Readers Theatre: Its Effectiveness in Improving Reading Fluency, Student Motivation, and Attitudes Toward Reading Among Second-Grade Students. The Pennsylvania State University.

Smith, S. (2010). A Preliminary Analysis of Narratives on the Impact of Training in Solution-Focused Therapy Expressed by Students Having Completed a 6-month Training Course. Journal of Psychiatric and Mental Health Nursing, 17, 105110. https://doi.org/10.1111/j.1365-2850.2009.01492.x

Sumarwiyah, S., Zamroni, E., \& Hidayati, R. (2015). Solution Focused Brief Counseling (Sfbc): Alternatif Pendekatan Dalam Konseling Keluarga. Jurnal Konseling Gusjigang, 1(2). https://doi.org/10.24176/jkg.v1i2.409

Texas Education Agency. (2018). The Dyslexia Handbook: Procedures Concerning Dyslexia and Related Disorders. Retrieved from https://throck.socs.net/vimages/shared/vnews/stories/48ce762e8414b/2018Dyslexia-Handbook_Approved_Accomodated_12_11_2018\%282\%29.pdf

Trepper, T. S., \& Mccollum, E. E. (2010). Solution Focused Therapy Treatment Manual for Working with Individuals Research Committee of the Solution Focused Brief Therapy Association 2010.

Woods, K., Bond, C., Humphrey, N., Symes, W., \& Green, L. (2011). Systematic Review of Solution Focused Brief Therapy (SFBT) with Children and Families. University of Manchester. 